JIIA, VOLUME 8 No. 1, FEBRUARI 2020

\title{
FAKTOR-FAKTOR YANG MEMENGARUHI MINAT PEMUDA PEDESAAN DALAM MELANJUTKAN USAHATANI PADI DI KABUPATEN LAMPUNG TENGAH
}

\author{
(Affecting Factors on Rural Youth Interest to Continue Rice Farming in Lampung Tengah Regency)
}

Alvita Raissa Marza, R Hanung Ismono, Eka Kasymir

Jurusan Agribisnis, Fakultas Pertanian, Universitas Lampung, J1. Prof. Dr. Soemantri Brodjonegoro No. 1

Bandar Lampung 35141, e-mail: hanung.ismono@fp.unila.ac.id

\begin{abstract}
This research aims to analyze the income of rice farming, the factors affecting of rural youth interest to continue rice farming, pull and push factors to work in agriculture sector. This research was purposively conducted in Trimurjo Sub District and Seputih Banyak Sub District, Central Lampung Regency from March to April 2018. There are 63 respondents taken by using proportional random sampling. The data of this research are collected by using survey method. The research data was analyzed bydescriptive qualitativeand quantitative. The descriptive qualitative and quantitative analysis was used to analyze farm income, binary logistic regression, and Spearman test. The results of this research show that the income of rice farming is Rp15.181.983,23 in the first planting season and Rp16.931.595,67 in the second planting season. Factors affecting of youth interest to continue rice farming are land area, age, education level, distance of youth residence to the city center. The pull factors to work in agriculture sector are the income of rice farming and availability of land area. The push factors to work in agriculture sector are limited employment opportunities, low level of education and too much free time.
\end{abstract}

Key words: farm, interest, pull factor, push factor, youth

\section{PENDAHULUAN}

Sektor pertanian memiliki beberapa peran penting bagi suatu negara.Salah satu peran sektor pertanian adalah menyerap tenaga kerja di Indonesia. Menurut BPS (2017), jumlah tenaga kerja di sektor pertanian tahun 2014 sampai tahun 2016 semakin berkurang setiap tahunnya. Jumlah tenaga kerja pada tahun $2015,40.122 .816$ orang dan berkurang sebanyak 4,57 persen pada tahun 2016. Sektor pertanian terdiri dari beberapa subsektor, salah satunya adalah subsektor tanaman pangan. Keadaan tenaga kerja pada subsektor tanaman pangan di Indonesia dan Provinsi Lampung tidak hanya terjadi penurunan jumlah, tetapi juga mengalami penurunan jumlah tenaga kerja yang berusia antara 16 sampai 24 tahun dan didominasi oleh tenaga kerja yang berusia 60 tahun lebih. Menurut Departemen Pertanian (2014), tenaga kerja yang berusia antara 16 sampai 24 memegang persentase terkecil, yaitu kurang dari $10 \%$ dari keseluruhan jumlah tenaga kerja di Indonesia dan atau Provinsi Lampung.

Tenaga kerja yang berusia 16 sampai 24 tahun merupakan usia pemuda yang merujuk pada UNESCO dan International Youth Year yang diselenggarakan pada tahun 1985. Pemuda memiliki peranan penting dalam lingkungan masyarakat terutama sebagai penerus dari generasi sebelumnya untuk melakukan pembangunan, sehingga pemuda pedesaan memiliki peranan dalam melanjutkan usahatani terdapat di desa yang telah dibuat oleh generasi sebelumnya guna melanjutkan pembangunan. Salah satu penyebab jumlah tenaga kerja yang berusia16-24 tahun sedikit di subsektor tanaman pangan adalah minat pemuda untuk bekerja di tanaman pangan yang rendah. Menurut Hadinoto (1998), minat seseorang dipengaruhi dua faktor, yaitu faktor dari dalam dan faktor dari luar diri seseorang.

Kabupaten Lampung Tengah merupakan salah satu kabupatendi Provinsi Lampung yang memiliki potensi baik di subsektor tanaman pangan. Tanaman pangan merupakan segala jenis tanaman pokok yang di dalamnya terkandung karbohidrat dan protein yang dapat digunakan sebagai sumber energi bagi manusia.Salah satu tanaman pangan yang biasanya dikonsumsi oleh sebagian besar masyarakat Indonesia adalah tanaman padi. Berdasarkan data jumlah petani yang didapatkan dari Badan Ketahanan Pangan dan Penyuluhan Pertanian Kabupaten Lampung Tengah, jumlah petani pada tahun 2008 dan 2017 menurun secara signifikan, yaitu sebesar 19,87 persen dari jumlah petani tahun 2008. Penurunan jumlah petani di Kabupaten Lampung Tengah 
salah satunya dapat disebabkan oleh minat pemuda pedesaan yang masih rendah dalam melanjutkan usahatani. Minat pemuda pedesaan yang rendah membuat peneliti tertarik untuk melakukan penelitian terkait dengan faktor-faktor yang dapat mempengaruhi minat pemuda pedesaan dalam melanjutkan usahatani padi di Kabupaten Lampung Tengah. Berdasarkan masalah yang ada, maka penelitian ini bertujuan untuk mengetahui pendapatan usahatani padi, mengetahui faktorfaktor yang dapat mempengaruhi minat pemuda pedesaan dalam melanjutkan usahatani padi, dan mengetahui faktor pendorong dan penarik pemuda pedesaan untuk bekerja di sektor pertanian Kabupaten Lampung Tengah.

\section{METODE PENELITIAN}

Penelitian ini dilakukan di Desa Simbar Waringin dan Desa Purwodadi Kecamatan Trimurjo serta Desa Sumber Fajar dan Desa Sumber Baru Kecamatan Seputih Banyak Kabupaten Lampung Tengah dengan menggunakan metode survei. Pemilihan lokasi dilakukan karena Kecamatan Trimurjo dan Kecamatan Seputih Banyak merupakan kecamatan yang memiliki produktivitas padi yang cukup tinggi di Kabupaten Lampung Tengah. Penentuan lokasi juga disebabkan Kecamatan Trimurjo merupakan kecamatan yang dekat dari pusat perkotaan dan Kecamatan Seputih Banyak merupakan kecamatan yang jauh dari pusat perkotaan. Jumlah sampel sebanyak 63 pemuda pedesaan dan 63 petani yang merupakan orang tua pemuda pedesaan. Jumlah sampel dihitung berdasarkan teori Isaac dan Michael dalam Sugiarto, at al.(2003) dan dipilih dengan metode proportional randomsampling.Pengambilan data dilakukan pada bulan Maret - April 2018.

Data yang digunakan dalam penelitian ini adalah data primer dan data sekunder. Data primer yang diperoleh dari wawancara langsung dengan pemuda pedesaan, sedangkan data sekunder yang diperoleh melalui sumber yang memiliki keterkaitan dengan permasalahan penelitian seperti Badan Pusat Statistik, Dinas Pertanian Kabupaten Lampung Tengah, Departemen Pertanian Indonesia, Kantor Kecamatan Seputih Banyak, Kantor Kecamatan Trimurjo, Kantor Desa Simbar Waringin dan Purwodadi Kecamatan Trimurjo, Kantor Desa Sumber Fajar dan Sumber Baru Kecamatan Seputih Banyak dan dari literatur yang relevan.

Metode yang digunakan untuk menganalisis pendapatan usahatani padi adalah analisis pendapatan yang meliputi analisis biaya, pendapatan, dan R/C ratio. Saputra, Prasmatiwi, dan Ismono (2017) menyatakan bahwa pendapatan usahatani diperoleh dengan menghitung selisih antara penerimaan dan total biaya yang dikeluarkan pada usahatani.

Faktor-faktor yang mempengaruhi minat pemuda pedesaan untuk melanjutkan usahatani padi dianalisis menggunakan regresi logistik (logistic regression model). Variabel dependen adalah minat pemuda pedesaan. Hasil kategorisasi minat pemuda pedesaan dalam melanjutkan usahatani padi diketahui dengan menggunakan kuesioner yang berpedoman pada Likert's Summated Rating Scale (LSRS). Pertanyaan untuk mengetahui minat pemuda pedesaan berdasarkan lima indikator, diantaranya yakni rasa senang, ketertarikan, keterlibatan, kemauan, dan semangat dalam usahatani padi. Hasil jawaban pemuda pedesaan dilakukan uji validitas dan uji reabilitas.Variabel independent terdiri dari, tingkat pendapatan $\left(\mathrm{X}_{1}\right)$, luas lahan usahatani $\left(\mathrm{X}_{2}\right)$, usia pemuda pedesaan $\left(\mathrm{X}_{3}\right)$, tingkat pendidikan $\left(\mathrm{X}_{4}\right)$, intensitas membantu usahatani padi orang tua $\left(\mathrm{X}_{5}\right)$, status kepemilikan lahan $\left(D_{1}\right)$, dan jarak tempat tinggal dari pusat kota $\left(D_{2}\right)$. Metode pengolahan data dilakukan dengan metode tabulasi, komputerisasi (Microsoft Excell), dan menggunakan SPSS. Menurut Winarno (2007) dalam Trisnata, Ismono, dan Soelaiman (2017), secara sistematis model dituliskan dalam persamaan sebagai berikut :

$$
\begin{aligned}
& \mathrm{Pi}=\mathrm{F}(\mathrm{Zi}) \\
& =F\left(\alpha+\beta_{1} X_{1}+\beta_{2} X_{2}+\beta_{3} X_{3}+\beta_{4} X_{4}+\beta_{5} X_{5}+\right. \\
& \delta_{1} \mathrm{D}_{1}+\delta_{2} \mathrm{D}_{2}+\mathrm{e}
\end{aligned}
$$

Dimana untuk menghitung Zi dengan rumus :

$$
\begin{aligned}
\mathrm{Zi}= & \operatorname{Ln} \frac{\mathrm{Pi}}{1-\mathrm{Pi}}=\alpha+\beta_{1} \mathrm{X}_{1}+\beta_{2} \mathrm{X}_{2}+\beta_{3} \mathrm{X}_{3}+\beta_{4} \mathrm{X}_{4}+\beta_{5} \\
& \mathrm{X}_{5}+\delta_{1} \mathrm{D}_{1}+\delta_{2} \mathrm{D}_{2}+\mathrm{e} \ldots \ldots \ldots \ldots \ldots \ldots \ldots \ldots \ldots . . .
\end{aligned}
$$

Keterangan :

$\mathrm{Zi}=$ Peluang pemuda pedesaan ke-i menentukan tingkat minat,dimana :

$\mathrm{P}_{1} \quad=$ Peluang pemuda pedesaan untuk berada pada tingkat minat tinggi

$\mathrm{P}_{0} \quad=$ Peluang pemuda pedesaan untuk berada pada tingkat minat rendah

$\alpha, \beta=$ Koefisien regresi

$\beta_{1}-\beta_{5}=$ Koefisien variabel bebas

$\mathrm{X}_{1} \quad=$ Tingkat Pendapatan Usahatani

$\mathrm{X}_{2} \quad=$ Luas lahan usahatani

$\mathrm{X}_{3} \quad=$ Usia pemuda pedesaan

$\mathrm{X}_{4} \quad=$ Tingkat pendidikan 


$$
\begin{aligned}
\mathrm{X}_{5}= & \text { Intensitas membantu usahatani padi orang } \\
& \text { tua } \\
\mathrm{D}_{1}= & \text { Status kepemilikan lahan } \\
& (1)=\text { milik sendiri } \\
& (0)=\text { tidak milik sendiri } \\
\mathrm{D}_{2} \quad= & \text { Jarak tempat tinggal dari pusat perkotaan } \\
& (1)=\text { Dekat dari pusat perkotaan } \\
& (0)=\text { Jauh dari pusat perkotaan } \\
\mathrm{e} \quad & \text { Error term }
\end{aligned}
$$

Model regresi logistik biner dilakukan beberapa pengujian statistika untuk mengetahui bermakna atau tidaknya variabel dan model yang digunakan. Uji Hosmer and Lemeshow dengan pendekatan metode Chi Squaredilakukan untuk mengetahui kecocokan (goodness of fit) dari model yang digunakan. Apabila nilai signifikansi di atas 0,10, maka model sudah memenuhi (Model fit). Pengujian signifikansi pada regresi logistik dapat dibagi menjadi dua ialah pengujian secara parsial dan pengujian secara simultan atau serentak. Pengujian secara parsial dapat dilakukan dengan menggunakan Uji Wald, sedangkan pengujian secara simultan dilakukan dengan Uji Overal Model Fit. Menafsirkan koefisien dalam model Regresi Logistik dilakukan berdasarkan koefisien rasio odds.

Faktor pendorong dan penarik pemuda pedesaan dalam bekerja di sektor pertanian khususnya usahatani padi diketahui dengan menggunakan skala ordinal yang berpedoman pada Likert's Summated Rating Scale (LSRS). Terdapat tujuh variabel dalam daftar pertanyaan, yaitu (1) tingkat pendapatan sektor pertanian, (2) keterbatasan kesempatan pekerjaan lain, (3) keterbatasan pendidikan yang dimiliki, (4) kehendak orang tua, (5) mengisi waktu luang, (6) luas lahan yang tersedia, (7) ajakan teman. Hasil jawaban pemuda pedesaan dilakukan uji validitas dan reliabilitas. Persepsi pemuda disimpulkan dengan rumus kategorisasi, yaitu sebagai berikut:

Rentang Kelas $=\frac{\text { skor tertinggi-skor terendah }}{\text { banyak kelas }}$

Persepsi pemuda pedesaan dilakukan uji hipotesis dengan menggunakan uji Spearman. Uji Spearman dilakukan untuk mengetahui signifikansi hubungan antara persepsi pemuda faktor penarik dan faktor pendorong dengan minat pemuda pedesaan dalam melanjutkan usahatani padi.

\section{HASIL DAN PEMBAHASAN}

\section{Karakteristik Responden}

Umur responden pemuda pedesaan umumya berkisar di antara 19-21 tahun dan mayoritas pemuda memiliki tingkat pendidikan SLTA. Umur responden petani padi umumnya berkisar antara 47-56 tahun dan seluruh petani pernah mendapatkan pendidikan formal dengan tingkat pendidikan terendah SD dan tertinggi S1. Mayoritas petani mengolah lahan dengan status kepemilikan lahan milik sendiri dengan luas lahan antara 0,25-0,5 ha. Mayoritas petani memiliki jumlah tanggungan keluarga sebanyak 3-4 orang yakni sebesar 80,33 persen responden petani.

\section{Analisis Pendapatan Usahatani Padi}

Analisis pendapatan usahatani padi dengan menghitung penerimaan dan biaya per hektar per musim tanam. Hasil produksi usahatani padi petani responden dijual dalam bentuk gabah basah. Berikut penerimaan, biaya dan pendapatan usahatani padi (MT 1 dan MT 2) petani dapat dilihat pada Tabel 1.Penerimaan pada MT 1 sebesar Rp21.636.537,68 lebih kecil dari penerimaan pada MT 2 sebesar Rp23.294.908,49. Pendapatan atas biaya tunai sebesar Rp15.181.983,23 pada MT 1 lebih kecil dibandingkan MT 2 sebesar Rp16.931.595,67. Pendapatan atas biaya total pada MT 1 sebesar Rp9.548.862,18 lebih kecil dibandingkan MT 2 sebesar Rp11.298.474,63. Perbedaan pendapatan usahatani disebabkan harga jual pada MT 2 yang lebih tinggi dari MT1. Psikiatri (2015) menyatakan jika produksi dan harga jual semakin tinggi, maka dapat meningkatkan penerimaan dan pendapatan.

Tabel 1. Perhitungan biaya, penerimaan, dan pendapatan per hektar usahatani padi

\begin{tabular}{lrr}
\hline \multicolumn{1}{c}{ Komponen } & \multicolumn{1}{c}{ MT 1 (Rp) } & \multicolumn{1}{c}{ MT 2 (Rp) } \\
\hline A. Produksi & $5.169,14$ & $4.786,63$ \\
B. Harga Jual & $4.185,71$ & $4.866,67$ \\
C. Penerimaan & $21.636 .537,68$ & $23.294 .908,49$ \\
D. Biaya Tunai & $6.452 .830,11$ & $6.363 .312,82$ \\
E. Biaya Diperhitungkan & $5.633 .121,04$ & $5.633 .121,04$ \\
F. Total Biaya (B+C) & $12.085 .951,15$ & $11.996 .433,87$ \\
Pendapatan atas Biaya Tunai & $15.183 .707,56$ & $16.931 .595,67$ \\
(C-D) & & \\
Pendapatan atas Biaya Total & $9.550 .586,52$ & $11.298 .474,63$ \\
(C-F) & & \\
R/C atas Biaya Tunai & 3,35 & 3,66 \\
R/C atas Biaya Total & 1,79 & 1,94 \\
\hline
\end{tabular}


Tabel 2. Perhitungan kontribusi pemuda pedesaan terhadap pendapatan tunai dan pendapatan total usahatani padi

\begin{tabular}{|c|c|c|}
\hline Keterangan & MT 1 & MT 2 \\
\hline $\begin{array}{l}\text { Pendapatan atas Biaya } \\
\text { Tunai per } 1 \text { ha (Rp) }\end{array}$ & $15.181 .983,23$ & $16.931 .595,67$ \\
\hline $\begin{array}{l}\text { Pendapatan atas Biaya } \\
\text { Total per } 1 \text { ha }(\mathrm{Rp})\end{array}$ & $9.548 .862,18$ & $11.298 .474,63$ \\
\hline $\begin{array}{l}\text { Rata-Rata Kontribusi } \\
\text { Pemuda Pedesaan (Rp) }\end{array}$ & $272.756,25$ & $272.756,25$ \\
\hline $\begin{array}{l}\text { Persentase Kontribusi } \\
\text { Pemuda dalam Pendapatan } \\
\text { atas Biaya Tunai (\%) }\end{array}$ & 1,80 & 1,61 \\
\hline $\begin{array}{l}\text { Persentase Kontribusi } \\
\text { Pemuda dalam Pendapatan } \\
\text { atas Biaya Total }(\%)\end{array}$ & 2,86 & 2,41 \\
\hline
\end{tabular}

Hasil perhitungan nilai $\mathrm{R} / \mathrm{C}$ atas biaya tunai pada musim tanam pertama sebesar 3,35 lebih kecil dari pada pada musim tanam kedua sebesar 3,66. Perhitungan nilai $\mathrm{R} / \mathrm{C}$ atas biaya diperhitungkan musim tanam pertama sebesar 1,79, sedangkan pada musim tanam kedua sebesar 1,94. Jika dibandingkan dengan penelitian yang dilakukan oleh Handayani, Effendi, dan Viantimala (2011) yang memperoleh nilai $\mathrm{R} / \mathrm{C}$ rasio sebesar 1,55. Nilai R/C rasio pada penelitian Handayani, Effendi, dan Viantimala (2011) lebih kecil dari penelitian ini yang menunjukkan bahwa usahatani padi di lokasi penelitian lebih menguntungkan karena pada saat penelitian harga jual gabah sedang tinggi.

Pemuda pedesaan memiliki kontribusi terhadap pendapatan usahatani padi karena mereka membantu kegiatan usahatani padi.Kontribusi pemuda pedesaan terhadap pendapatan usahatani dapat dilihat pada Tabel 2. Data Tabel 2menunjukkan bahwa kontribusi pemuda pedesaan sebesar Rp272.756,25. Kontribusi pemuda pedesaan terhadap pendapatan usahatani padi tunai dan total kurang dari 3 persen. Kontribusi pemuda pedesaan yang kecil terhadap pendapatan usahatani padi disebabkan karena mayoritas pemuda pedesaan tidak ingin terlibat dalam kegiatan usahatani padi. Pemuda pedesaan lebih memilih kegiatan selain usahatani padi, seperti sekolah, bermain voli, dan kegiatan lain. Hal ini tidak sejalan dengan penelitian Sukayat dan Dika (2017) yang menyatakan bahwa terdapat kecendrungan pemuda desa tertarik dalam melakukan aktivitas pada sektor pertanian.

\section{Faktor-Faktor yang Mempengaruhi Minat Pemuda Pedesaan dalam Melanjutkan Usahatani Padi}

Minat pemuda pedesaan diketahui menggunakan pertanyaan tertutup dengan skala likert.Hasil jawaban dari 63 pemuda pedesaan dilakukan pengujian validitas dan realibilitas. Setelah hasil jawaban pemuda pedesaan valid dan reliabel, maka skor dari jawaban pemuda pedesaan dikategorikan menjadi dua, yaitu minat rendah dan minat tinggi. Hasil kategorisasi tingkat minat pemuda pedesaan dalam melanjutkan usahatani padi disajikan pada Tabel 3. Data Tabel 3 diketahui bahwa mayoritas pemuda memiliki tingkat minat yang rendah dalam melanjutkan usahatani padi sebanyak 35 pemuda dengan persentase sebesar 55,56 persen.

Variabel dependenadalah minat pemuda pedesaan dan variabel independenadalah tingkat pendapatan, luas lahan, umur, tingkat pendidikan, intensitas membantu usahatani, dan jarak kotadengan lingkungan pemuda diregresi dengan menggunakan model regresi logistik biner melalui SPSS. Namun, variabel hak milik lahan tidak dimasukkan ke dalam regresi, hal ini disebabkan karena nilai variabel tersebut kurang bervariasi.Hasil analisis regresi faktor-faktor yang mempengaruhi minat pemuda pedesaan dalam melanjutkan usahatani disajikan pada Tabel 4.Hasil analisis regresi logistik biner pada pengujian Hosmer Lemeshow menghasilkan nilai Sig. 0,972> $\alpha \quad(10 \%)$ menunjukkan bahwa model regresi logistik yang digunakan dalam penelitian ini sudah mampu mejelaskan data yang ada. Nilai Negelkerke R-Square 0,867 yang dihasilkan berarti bahwa variabel pendapatan, luas lahan, umur, tingkat pendidikan, intensitas membantu usahatani padi, hak kepemilikan lahan dan jarak dari lingkungan pemuda dengan kota dapat menjelaskan 86,7 persen pembentukan variabel minat pemuda pedesaan dalam melanjutkan usahatani padi.

Tabel 3. Hasil kategorisasi tingkat minat pemuda pedesaan dalam melanjutkan usahatani padi

\begin{tabular}{|c|c|c|c|c|}
\hline No. & Kategori & Interval Skor & $\begin{array}{l}\text { Jumlah } \\
\text { Pemuda }\end{array}$ & $\begin{array}{c}\text { Persentase } \\
(\%)\end{array}$ \\
\hline 1. & Minat Tinggi & $115-190$ & 28 & 44,44 \\
\hline 2. & Minat Rendah & $38-114$ & 35 & 55,56 \\
\hline \multicolumn{3}{|c|}{ Jumlah } & 63 & 100,00 \\
\hline
\end{tabular}


Tabel4. Hasil regresi logistik biner faktor-faktor yang mempengaruhi minat pemuda pedesaan dalam melanjutkan usahatani padi

\begin{tabular}{lclr}
\hline \multicolumn{1}{c}{ Variabel } & B & Sig. & Odds Ratio \\
\hline Pendapatan $\left(\mathrm{X}_{1}\right)$ & $-0,001^{*}$ & 0,080 & 0,999 \\
Luas Lahan $\left(\mathrm{X}_{2}\right)$ & $0,003^{* *}$ & 0,031 & 1,003 \\
Umur $\left(\mathrm{X}_{3}\right)$ & $-0,552^{* *}$ & 0,036 & 0,576 \\
Pendidikan $\left(\mathrm{X}_{4}\right)$ & $-0,594^{*}$ & 0,073 & $-0,552$ \\
Intensitas & 0,033 & 0,239 & 1,034 \\
Membantu $\left(\mathrm{X}_{5}\right)$ & $-0,714$ & 0,799 & 0,490 \\
Jarak Kota $\left(\mathrm{D}_{2}\right)$ & 5,696 & 0,322 & 297,653 \\
\hline Constant & & & \\
\hline
\end{tabular}

Tabel 26 menghasilkan model persamaan hasil analisis regresi logistik biner yang dihasilkan sebagai berikut.

$$
\begin{aligned}
\mathrm{Y}= & 5,696-0,001 \mathrm{X}_{1}+0,003 \mathrm{X}_{2}-0,552 \mathrm{X}_{3}- \\
& 0,594 \mathrm{X}_{4}+0,033 \mathrm{X}_{5}-0,714 \mathrm{D}_{2}
\end{aligned}
$$

Hasil analisis logistik terlihat bahwa pendapatan berpengaruh nyata dan signifikan terhadap minat pemuda pedesaan dalam melanjutkan usahatani padi. Variabel pendapatan memiliki nilai odds ratio sebesar 0,999 dan nilai signifikansi $0,080<\alpha$ $(10 \%)$. Semakin meningkatnya pendapatan usahatani sebesar Rp1, maka peluang untuk melanjutkan usahatani padi semakin meningkat sebesar 0,999 kali dengan asumsi semua variabel bebas lainnya tetap.Variabel luas lahan berpengaruh nyata dan signifikan terhadap minat pemuda pedesaan dalam melanjutkan usahatani padi yang ditunjukkan dengan nilai odds ratiovariabel luas lahan sebesar 1,003dan nilai signifikansi $0,031<\alpha(10 \%)$. Semakin meningkat luas lahan sebesar 1 hektar yang dimiliki orang tua pemuda pedesaan, maka peluang untuk melanjutkan usahatani padi semakin meningkat sebesar 1,003 kali dengan asumsi semua variabel bebas lainnya tetap.

Hasil regresi logistik menunjukkan bahwa umur berpengaruh nyata dan signifikan terhadap minat pemuda pedesaan dalam melanjutkan usahatani padi hal ini ditunjukkan dengan koefisien variabel umur dengan nilai odds ratio sebesar 0,576 dan nilai Sig. $0,036<\alpha(10 \%)$. Semakin bertambahnya umur pemuda pedesaan sebesar 1 tahun, maka peluang pemuda untuk melanjutkan usahatani padi semakin besar sebesar 0,576 kalidari pada tidak melanjutkan usahatani padi dengan asumsi semua variabel bebas lainnya tetap.Variabel tingkat pendidikan pemuda pedesaan berpengaruh nyata terhadap minat pemuda pedesaan dalam melanjutkan usahatani padi yang ditunjukkan dengan nilai odds ratiosebesar $-0,552$ dan memiliki nilai signifikansi $\quad 0,073<\alpha \quad(10 \%)$.Semakin bertambahnya pendidikan pemuda pedesaan sebesar 1 tahun, maka peluang pemuda untuk melanjutkan usahatani padi menurun sebesar 0,552 kali dari pada tidak melanjutkan usahatani padi.

Hasil regresi logistik menunjukkan bahwa intensitas membantu usahatani padi orang tua tidak berpengaruh nyata terhadap minat pemuda pedesaan dalam melanjutkan usahatani padi hal ini ditunjukkan dengan nilai odds ratiosebesar 1,034 dan nilai Sig. 0,239> $\alpha(10 \%)$. Variabel jarak antara lingkungan pemuda dengan kota tidak berpengaruh nyata terhadap minat pemuda pedesaan dalam melanjutkan usahatani padi dengan nilai odds ratio sebesar 0,490 dan nilai Sig. $0,799<\alpha(10 \%)$.

\section{Faktor Pendorong Pemuda Pedesaan Bekerja di Sektor Pertanian}

Faktor pendorong pemuda pedesaan untuk bekerja di sektor pertanian khususnya usahatani padi diketahui dengan menggunakan beberapa variabel, yaitu kesempatan pekerjaan lain, keterbatasan pendidikan, kehendak orang tua, mengisi waku luang, dan ajakan teman. Persepsi pemuda pedesaan diketahui dengan menggunakan pertanyaan dengan skala likert.Hasil jawaban pemuda pedesaan dilakukan uji validitas dan reliabilitas. Skor jawaban pemuda pedesaan dikategorikan menjadi dua kategori, yaitu faktor pendorong dan bukan faktor pendorong.

Tabel 5. Hasil kategori persepsi pemuda pedesaan mengenai masing-masing variabel merupakan faktor

\begin{tabular}{|c|c|c|c|c|c|}
\hline \multirow[b]{2}{*}{ Kategori } & \multicolumn{5}{|c|}{ Jumlah Persepsi Pemuda } \\
\hline & $\begin{array}{c}\text { Keterbatasan } \\
\text { Pekerjaan Lain }\end{array}$ & $\begin{array}{c}\text { Keterbatasan } \\
\text { Pendidikan }\end{array}$ & $\begin{array}{c}\text { Kehendak Orang } \\
\text { Tua }\end{array}$ & $\begin{array}{l}\text { Mengisi Waktu } \\
\text { Luang }\end{array}$ & $\begin{array}{l}\text { Ajakan } \\
\text { Teman }\end{array}$ \\
\hline Bukan Faktor Pendorong & 16 & 16 & 55 & 35 & 60 \\
\hline Faktor Pendorong & 47 & 47 & 8 & 28 & 3 \\
\hline
\end{tabular}
pendorong pemuda untuk bekerja di sektor pertanian 
Tabel 6. Hasil uji Spearman faktor pendorong pemuda pedesaan bekerja di sektor pertanian

\begin{tabular}{llcc}
\hline No. & \multicolumn{1}{c}{ Variabel } & Koefisien & Sig. \\
\hline 1. & Kesempatan Pekerjaan Lain & $0,596^{* * *}$ & 0,000 \\
2. & Keterbatasan Pendidikan & $0,571^{* * *}$ & 0,000 \\
3. & Kehendak Orang Tua & $0,407^{* * *}$ & 0,001 \\
4. & Mengisi Waktu Luang & $0,656^{* * *}$ & 0,000 \\
5. & Ajakan Teman & $0,595^{* * *}$ & 0,000 \\
\hline
\end{tabular}

Hasil kategori persepsi pemuda pedesaan mengenai masing-masing variabel merupakan faktor pendorong pemuda untuk bekerja di sektor pertanian dapat dilihat pada Tabel 5. Tabel 5 menunjukkan bahwa variabel yang merupakan faktor pendorong adalah keterbatasan kesempatan kerja dan keterbatasan pendidikan, sedangkan variabel bukan faktor pendorong adalah kehendak orang tua, mengisi waktu luang, dan ajakan teman.

Hasil kategori persepsi faktor pendorongdilakukan uji Spearman. Uji Spearman dilakukan untuk mengetahui hubungan antara persepsi pemuda pedesaan faktor pendorong dengan minat mereka dalam melanjutkan usahatani padi. Hasil uji Spearman disajikan pada Tabel 6. Tabel 6 diketahui bahwa variabel keterbatasan pekerjaan lain, keterbatasan pendidikan, kehendak orang tua, mengisi waktu luang, dan ajakan teman memiliki nilai Sig. kurang dari $\alpha 10$ persen, artinya terdapat hubungan antara persepsi faktor pendorong dengan kerja dengan minat pemuda pedesaan dalam melanjutkan usahatani padi. Persepsi pemuda pedesaan mengenai keterbatasan pendidikan merupakan faktor pendorong memiliki hubungan dengan minat pemuda pedesaan dalam melanjutkan usahatani padi, sesuai dengan penelitian Sari (2014) yang menyatakan bahwa keputusan remaja dalam memilih pekerjaan tidak lepas dari tingkat pendidikan.

\section{Faktor Penarik Pemuda Pedesaan Bekerja di Sektor Pertanian}

Faktor penarik pemuda pedesaan untuk bekerja di sektor pertanian khususnya usahatani padi diketahui dengan menggunakan dua variabel, yaitu tingkat pendapatan dan ketersediaan lahan.Persepsi pemuda pedesaan faktor penarik bekerja di sektor pertanian diketahui dengan menggunakan pertanyaan berskala likert. Hasil skor jawaban pemuda pedesaan dikategorikan menjadi dua kategori. Hasil kategori persepsi pemuda pedesaan mengenai masing-masing variabel merupakan
Tabel 7. Hasil kategori persepsi pemuda pedesaan mengenai masing-masing variabel faktor penarik untuk bekerja di sektor pertanian

\begin{tabular}{lcc}
\hline \multirow{2}{*}{ Kategori } & \multicolumn{2}{c}{ Jumlah Persepsi Pemuda } \\
\cline { 2 - 3 } & $\begin{array}{c}\text { Tingkat } \\
\text { Pendapatan }\end{array}$ & $\begin{array}{c}\text { Ketersediaan } \\
\text { Lahan }\end{array}$ \\
\hline Bukan Faktor Penarik & 29 & 27 \\
Faktor Penarik & 34 & 36 \\
\hline
\end{tabular}

Tabel 8. Hasil uji Spearman variabel faktor penarik pemuda pedesaan bekerja di sektor pertanian

\begin{tabular}{llcc}
\hline No. & Variabel & Koefisien & Sig. \\
\hline 1. & Tingkat pendapatan & $0,523^{* * *}$ & 0,000 \\
2. & Ketersediaan lahan & $0,443^{* * *}$ & 0,000 \\
\hline
\end{tabular}

faktor penarik atau bukan faktor penarik disajikan dalam Tabel 7.

Tabel 7 menunjukkan bahwa mayoritas pemuda memiliki persepsi bahwa variabel tingkat pendapatan dan ketersediaan lahan merupakan faktor penarik pemuda bekerja di sektor pertanian. Hasil kategori persepsi faktor pendorong dilakukan uji Spearman.Uji Spearman dilakukan untuk mengetahui hubungan antara persepsi pemuda pedesaan faktor penarik dengan minat mereka dalam melanjutkan usahatani padi. Hasil uji Spearman disajikan pada Tabel 8.Data Tabel 8 menunjukkan bahwa variabel tingkat pendapatan dan ketersediaan lahan memiliki nilai Sig. kurang dari $\alpha 10$ persen, artinya terdapat hubungan antara persepsi pemuda faktor penarik dengan minat pemuda pedesaan dalam melanjutkan usahatani padi. Hal ini sesuai dengan penelitian yang dilakukan oleh Muhammad, Agustono, dan Wijianto (2016) yang menyatakan bahwa luas lahan dan pendapatan mempengaruhi minat petani dalam melanjutkan usahatani padi.

\section{KESIMPULAN}

Rata-rata pendapatan usahatani padi per hektar pada MT 1 berdasarkan biaya tunai sebesar Rp15.181.983,23 dan nisbah penerimaan dengan biaya (R/C Rasio) tunai sebesar 3,35. Pendapatan berdasarkan biaya tunai pada MT 2 sebesar Rp16.931.595,67 dan nisbah penerimaan dengan biaya (R/C Rasio) tunai sebesar 3,66.Pemuda pedesaan memiliki kontribusi terhadap pendapatan sebesar kurang 3 persen dari pendapatan tunai dan total. Faktor-faktor yang mempengaruhi minat pemuda pedesaan dalam melanjutkan usahatani padi orang tua di Kabupaten Lampung Tengah 
adalah pendapatan, luas lahan, umur pemuda, dan tingkat pendidikan. Faktor pendorong pemuda pedesaan untuk bekerja di sektor pertanian khususnya usahatani padi adalah keterbatasan kesempatan kerja, tingkat pendidikan yang rendah, ajakan teman, kehendak orang tua, dan mengisi waktu luang. Faktor penarik pemuda pedesaan untuk bekerja di sektor pertanian khususnya usahatani padi adalah tingkat pendapatan dan ketersediaan luas lahan.

\section{DAFTAR PUSTAKA}

Achmad K. 2001. Cara Menggunakan dan Memaknai Analisis Asumsi Klasik Cetakan Pertama. Alfabeta. Bandung.

Badan Ketahanan Pangan dan Penyuluhan Pertanian Kabupaten Lampung Tengah. 2017. Jumlah petani di Kabupaten Lampung Tengah Pada Tahun 2008 dan 2017. Badan Ketahanan Pangan dan Penyuluan Pertanian Kabupaten Lampung Tengah. Lampung Tengah.

BPS [Badan Pusat Statistik] Provinsi Lampung. 2017. Jumlah Tenaga Kerja di Sektor Pertanian di Indonesia pada Tahun 20142016. BPS Provinsi Lampung. Bandar Lampung.

Departemen Pertanian. 2014. Statistik Ketenagakerjaan Sektor Pertanian Tahun 2014. http://pusdatin.setjen.pertanian.go.id/ tinymcpuk/gambar/file/statistik_tenaga_kerja 2014_1.pdf. [10 Desember 2017].

Hadinoto SR. 1998.Psikologi Perkembangan. Gadjah Mada University Press. Yogyakarta.

Handayani SA, Effendi I,dan Viantimala B. 2011. Analisis produksi dan pendapatan usahatani padi di Desa Pujo Asri Kecamatan Trimurjo Kabupaten Lampung Tengah. JIIA, 5(4) : 1-4. http://jurnal.fp.unila.ac.id/index. php/JIA/article/view/1752.[8 Mei 2018].

Muhammad A, Agustono A, dan Wijianto A. 2016. Faktor-faktor yang mempengaruhi minat petani dalam berusahatani padi di Kecamatan Kebakkramat Kabupaten Karanganyar. Jurnal Sosial Ekonomi Pertanian Agribisnis, 12 (2) : 1-9. https://jurnal.uns.ac.id/sepa/article/view/142 26. [20 Desember 2017].

Psikiatri A, Widjaya S, dan Nurmayasari I. 2015. Tingkat pendapatan dan nilai tambah usahatani padi pada petani peserta program pascapanen di Kabupaten Lampung Timur. JIIA, 3(1) : 70-71. http://jurnal.fp.unila.ac.id/ index.php/JIA/article/view/1019/924.[26 Mei 2016].

Saputra J, Prasmatiwi FE, dan Ismono RH. 2017. Pendapatan dan risiko usahatani jahe di Kecamatan Penengahan Kabupaten Lampung Selatan. JIIA, 5(4): 392. http://jurnal.fp.unila.ac.id/index.php/JIA/arti cle/view/1748. [6 Mei 2018].

Sari M. 2014. Pergeseran Pekerjaan Remaja dari Sektor Pertanian ke Sektor Industri. Universitas Udayana. Bali.

Sugiarto, Siagian D, Sunaryanto LT, dan Oetomo DS. 2003. Teknik Sampling. PT Gramedia Pustaka Utama. Jakarta.

Sukayat Y dan Dika S. 2017. Perilaku pemuda desa dalam kegiatan pertanian (beberapa kasus pemuda desa di agroekosistem dataran tinggi, dataran medium dan dataran rendah). Agrivet Journal, 5(1): 49-55. http://jurnal. unma.ac.id/index.php/AG/article/view/604.[ 02 Januari 2018].

Trisnata DP, Ismono RH, dan Soelaiman A. 2017.Analisis kelayakan finansial dan faktor-faktor yang mempengaruhi keputusan penangkaran dalam mengusahakan bibit karet bersertifikat di Kecamatan Abung Semuli Kabupaten Lampung Utara. JIIA, 5(1): 43-52. http://jurnal.fp.unila.ac.id/ index.php/JIA/article/view/1673. [ [8 Mei 2018]. 